TEME, г. XLII, бр. 1, јануар - март 2018, стр. 129-141

Прегледни рад

Примљено: 2. 11. 2016.

DOI: 10.22190/TEME1801129D

Одобрено за штампу: 12. 3. 2018.

UDK 336.71(497+4-672EU)

\title{
СТЕЧАЈ БАНАКА И ФИНАНСИЈСКИХ УСТАНОВА У ЗЕМАЉАМА КАНДИДАТИМА ЗА ЕУ ЗАПАДНОГ БАЛКАНА
}

\author{
Ђуро М. Ђурић ${ }^{1}$, Владимир М. Јовановић ${ }^{2}$, \\ Мирјана М. Мисаиловић ${ }^{3^{*}}$ \\ ${ }^{1}$ Комора извршитеља, Београд, Србија \\ ${ }^{2}$ Факултет за економију и инжењерски менаџмент у Новом Саду, Србија \\ З3авод за уџбенике и наставна средства, Београд, Србија \\ djuro.djuric@komoraizvrsitelja.rs
}

\begin{abstract}
Апстракт
Циљ овог рада је да прикаже правно уређење стечаја банака и других финансијских установа у појединим земљама западног Балкана (Србија, Црна Гора и БЈР Македонија) и његов развој под утицајем прописа ЕУ. Ово питање је постало посебно занимљиво од почетка светске финансијске кризе 2008. године. Банке и финансијске установе из земаља ЕУ налазе се међу главним играчима на финансијским тржиштима. Криза је показала да модели који су раније постојали нису били довољни и да нису омогућили адекватан ниво сарадње између држава чланица како би се смањило ширење негативних дејстава појединих стечајних поступака и проблема појединих финансијских установа широм ЕУ и широм света. Због тога су потребне промене у прописима и, заиста, извесне промене јесу извршене. Овај рад покушава да сагледа и оцени проширење ЕУ, које је тренутно на врху политичке и економске агенде ЕУ, земље кандидате које су у процесу усклађивања свог законодавства и праксе, у циљу боље припреме за преговоре са ЕУ, али и бољег усклађивања својих економских услова и тржишта са земљама ЕУ, што их чини атрактивнијим за потенцијалне стране инвеститоре. Покушаћемо да дамо кратку анализу о томе како је неколико земаља кандидата за ЕУ са западног Балкана реаговало на описане промене у прописима ЕУ, који се односе на финансијске установе, и решавало своје финансијске потешкоће.
\end{abstract}

Кључне речи: стечај, банке, финансијске установе, земље кандидати, ЕУ регулатива. 


\title{
INSOLVENCY OF BANKS AND FINANCIAL INSTITUTIONS THE EU CANDIDATE COUNTRIES IN WESTERN BALKANS
}

\begin{abstract}
The objective of this paper is to present the regulation of insolvency of banks and other financial institutions in some West Balkans countries (Serbia, Montenegro and FYROM) candidates for the EU membership and its development under the influence of the EU regulations. This question has become particularly interesting since the onset of the world financial crisis of 2008. Banks and financial institutions from the EU countries are among major players in financial markets. The crisis has shown that the models that have previously existed were not sufficient and did not enable an adequate level of cooperation between member states, in order to minimize the spreading of negative effects of individual insolvencies and problems of individual financial institutions across the EU and all over the world. Therefore, changes were needed in the regulations, and indeed, certain changes have been made. This paper tries to see and evaluate the enlargement of the EU which is currently not on top of the EU political and economic agenda, the candidate countries are in the process of adjusting their legislation and practices in order to be better prepared for negotiating with the EU, but also in order to make their respective economic conditions and markets more harmonized with the EU countries, therefore making them more attractive to potential foreign investors. We shall attempt to give a brief analysis of how several West Balkans EU candidate countries have reacted to the described changes in the EU regulations regarding financial institutions and handling their financial difficulties.
\end{abstract}

Key words: insolvency, banks, financial institutions, candidate countries, EU regulations.

\section{1. ПРОПИСИ ЕУ О СТЕЧАЈУ БАНАКА И ДРУГИХ ФИНАНСИЈСКИХ ИНСТИТУЦИЈА}

Питање стечаја банака и других финансијских установа постала је посебно „врућа тема” од почетка светске финансијске кризе 2008. године. Будући да су многе банке и друге финансијске установе из земаља ЕУ главни играчи на финансијским тржиштима широм света и пошто су неке од њих тешко погођене проблемима које је криза донела, природно је да се ЕУ и њени прописи у овој области нађу под лупом. Постојећи модели нису одговорили очекивањима, нити су омогућили адекватан ниво сарадње између држава чланица (Тодоровић, Вуксановић, Јакшић, 2015, стр. 159-174) како би се смањило ширење негативних ефеката појединих стечајних поступака и проблема појединих финансијских установа широм ЕУ и по целом свету.

Већ годинама главни регулаторни инструмент у овој области је Директива 2001/24/EC, од 4. априла 2001. године о реструктурирању и ликвидацији кредитних институција (Directive 2001/24/EC from April 4th 2001 on the reorganisation and winding up of credit institutions, $O J \mathrm{~L} 125,5.5 .2001$, p. 15-23). Она је поставила елементарна правила која државама чланицама дају значајну слободу да успоставе закон- 
ске режиме који би одговарали њиховим правним традицијама, економској политици, те циљевима и жељама. Неколико правила и принципа су најважнији:

- кредитна установа и њене филијале чине јединствену целину, подвргнуте надзору надлежних органа државе у којој је добила овлашћење које важи у целој заједници (матична држава чланица);

- управни или судски органи матичне државе чланице имају искључиву надлежност да одлучују о мерама реструктурирања предвиђеним у закону те државе чланице и да их спроводе;

- државе чланице дужне су да обавесте једна другу када предузимају мере у складу са овом директивом;

- према повериоцима кредитне установе треба да се поступа једнако, без обзира на државе чланице из које долазе;

- одлуке надлежних органа матичне државе чланице треба да се признају у другим државама чланицама без икаквих посебних формалности.

Финансијска криза која је почела 2008. године донела је неколико значајних стечајних поступака у финансијском сектору, које су углавном решавале националне владе на различите начине: од различитих врста bail-out-ова ${ }^{1}$, па све до потпуног банкротства и ex post интервенција. Догађаји су показали да се ефекти неуспеха једне финансијске установе могу ширити далеко преко националних граница. Преовладавао је закључак да власти укључених земаља, не само у матичној држави, буду укључене у процес доношења одлука и да редовни поступак за стечај нефинансијских компанија није у потпуности погодан за финансијске установе, посебно за оне које послују на међународном нивоу. Исто тако, успостављена су заједничка међународна финансијска средства за спасавање пропалих финансијских установа. Разарајуће економске последице кризе показале су да финансијски сектор тражи оштрије прописе и надзор.

Главна регулаторна реформа на нивоу ЕУ било је усвајање Директиве 2014/59/EC 15. маја 2014. године о успостављању оквира за опоравак и санацију кредитних установа и инвестиционих друштава (Directive 2014/59/EU from May $15^{\text {th }} 2014$ establishing a framework for the recovery and resolution of credit institutions and investment firms, $O J$ L 173, 12. 6. 2014, p. 190-348, EU Bank Recovery and Resolution

\footnotetext{
1 Bail-out je стање у којем компанија, појединац или влада пружа новчану помоћ компанији у тешкоћама како би се спречиле последице које могу произаћи из њене пропасти. Bail-out-ови могу бити у облику кредита, обвезница, акција или готовог новца. Они могу садржати обавезу повраћаја. Традиционално се bail-out-ови одвијају у индустријским и другим компанијама за које се сматра да више не могу да опстану или да поднесу велике губитке. Извор: www.investopedia.com. 1. 9. 2016.
} 
Directive, у даљем тексту: БРРД) $)^{2}$, који је такође изменио неколико других директива и уредаба ЕУ, укључујући Директиву 2001/24/ЕС.

Основне карактеристике правног режима који је поставио БРРД су следеће (детаљније на http://europa.eu/rapid/press-release_MEMO-14297_en.htm (14.9.2015)):

- циљ БРРД је да последице неуспеха финансијска установа (банка или инвестициона компанија која је у оквиру БРРД) сноси са својим акционарима и повериоцима, уместо пореских обвезника;

- финансијске установе морају да припреме потпуни план опоравка са мерама које се предузимају у различитим случајевима финансијских потешкоћа; ти планови се представљају у координацији са националним органима надлежним за санацију;

- власти надлежне за санацију овлашћене су да интервенишу у случају погоршања финансијског стања финансијске установе; мере укључују захтев да мере за опоравак план предузму саме установе, захтев да се управа промени, или чак именовање специјалног менаџера да замени постојећу управу финансијске установе која је у питању;

- када надлежни органи утврде да установа улази у тешкоће или неће успети да их избегне и када се сматра да би било које друге мере биле довољне у датим околностима, покреће се санација, што значи да орган санације може користити неки од инструмената за санацију који обезбеђује БРРД: продаја дела пословања без сагласности акционара, образовање установе „за премошћавање” (енгл. bridge institution $^{3}$ ) и „лоше банке" (енгл. bad bank ${ }^{4}$ ), који одваја добре и здраве делове установе од „лоших” делова, или чак помоћу bail-in

\footnotetext{
${ }^{2}$ Directive 2014/59/EU from May $15^{\text {th }} 2014$ establishing a framework for the recovery and

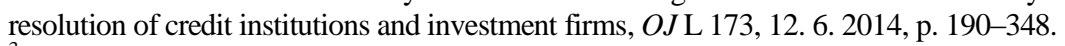

${ }^{3}$ Односи се на банку која је овлашћена да преузме имовину и обавезе друге банке, посебно банке у стечају. Банка за премошћавање обавезна је да настави пословање банке у стечају док она не постане солвентна преузимањем од другог субјекта или док не буде ликвидирана. Извор: www.investopedia.com. 1. 9. 2016.

${ }^{4}$ Односи се на банку образовану како би откупила лоше кредите банке са значајном количином лоших средстава по тржишној цени. Пребацивањем лоших средстава једне установе на лошу банку, банке чисте своје билансе од лоших средстава, али су исто тако принуђене на отпис средстава. Имаоци акција и обвезница морају поднети губитак средстава који произлази из овог решења (али не и депоненти). Банке које су постале неспособне за плаћање као резултат овог поступка могу бити докапитализоване, национализоване или ликвидиране. Извор: www.investopedia.com. 1. 9. 2016.

${ }^{5}$ Bail-in представља спасавање финансијске установе на ивици слома тако што њени повериоци и депоненти трпе терет губитка на својим средствима. На тај начин, bail-in представља супротност bail-out-у, који укључује спасавање финансијске установе од стране спољних чинилаца, обично националне владе која то чини средствима пореских обвезника. У пракси су bail-out-ови чешћи него bailin-ови, али у новије време, након бројних bail-out-ова, неке владе сада захтевају да инвеститори и депоненти банака поднесу терет губитака пре него порески
} 
инструмента, који омогућава да се обавезе уписују или претворе у капитал, тако да установа може да опстане као наставак пословања;

- од банака и инвестиционих фирми захтева се да дају финансијски допринос националним фондовима успостављеним за испуњење задатака предвиђених БРРД, на пример, стварање банке за премошћавање bridge bank и обезбеђивање капитала или кредита за њено пословање; доприноси установа треба да буду у сразмери са њиховим обавезама и профилима ризика (Burkert, 2015).

БРРД је донела одређене амандмане на Директиву 2001/24/EC, проширући свој домет, чиме су обухваћене инвестиционе фирме и њихове филијале, како је дефинисано Уредбом (ЕУ) бр. 575/2013 од 26. јуна 2013. године. Она је такође заменила одредбе о дужности информисања надлежних органа и познатих поверилаца о одредбама о дужности органа надлежних за санацију из члана 83 БРРД.

Иако проширење ЕУ тренутно није на врху политичке и економске агенде ЕУ, земље кандидати су у процесу усклађивања законодавства и праксе у циљу боље припреме за преговоре са ЕУ, али и одговарајућих економских услова и тржишта усклађених са земљама ЕУ (Анић, Маловић, Мисић, 2015, стр. 175-190), што их чини привлачнијим за потенцијалне стране инвеститоре (Ђурић, 2012, стр. 159-171). Покушаћемо да дамо кратку анализу о томе како је неколико земаља кандидата за ЕУ западног Балкана реаговало на описане промене у правилима ЕУ које се односе на финансијске установе и како су поступале у условима финансијских тешкоћа.

\section{2. ПРАВНИ ОКВИР У РЕПУБЛИЦИ СРБИЈИ}

На реформу законодавства у области банкарства у Србији у 2015. години значајно је утицала промена у законодавству ЕУ, нарочито нова Директива БРРД. Најпре, Скупштина Србије усвојила је потпуно нови закон о стечају и ликвидацији банака и друштава за осигурање (,Закон о стечају и ликвидацији банака и друштава за осигурање”, Службени гласник Републике Србије, бр. 14/2015). Овај закон уређује правни поступак који спада у оквир Директиве 2001/24/ ЕС о реорганизацији и ликвидацији кредитних установа, коja је такође ревидирана доношењем Директиве БРРД 2014. године (Јовановић, 2011, p. 228-304).

Овај закон односи се на стечај и ликвидацију банака, осигуравајућих друштава, као и компанија које пружају услуге финансијског лизинга, што значи да има за циљ да обезбеди исти правни оквир за све установе за које се сматра да су финансијске установе. Према овом закону, поступак стечаја и ликвидације покреће одлуком над-

обвезници. www.investopedia.com. 1. 9. 2016. 
лежног Привредног суда, где се поступак покреће на основу претходне одлуке Народне банке Србије (у даљем тексту: НБС). У случају стечаја, истовремено са доношењем одлуке да су испуњени услови за покретање стечајног поступка, НБС одузима дозволу за рад банци која је у питању (Ivanović, Balaban, 2009, стр. 43-52). Заинтересоване стране могу да покрену поступак за преиспитивање законитости одлуке НБС пред Управним судом. У том поступку, Управни суд може само да одлучи да та одлука није законита, да је поништи и пошаље га назад НБС да понови поступак, али суд не може да одлучи о самој ствари, у пуној јурисдикцији („Закон о стечају и ликвидацији банака и друштава за осигурање”, Службени гласник Републике Србије бр. 14/2015).

Органи стечајног поступка су суд, стечајни управник и одбор поверилаца. Агенција за осигурање депозита (у даљем тексту: АОД) поступа као стечајни управник у сваком случају ex lege. АОД одмах исплаћује депозите у износу у којем су осигурани законом, који тренутно износи 50.000 евра по појединачном депоненту. Суд објављује одлуку о покретању стечајног поступка, у којем одређује рок за пријављивање потраживања поверилаца банке у стечајном поступку, што би могло бити између 30 и 90 дана.

АОД прави попис имовине и обавеза банке, њених значајних уговора на снази, послова закључених у последњих 180 дана итд., као и почетни стечајни биланс. Током поступка, послови закључени од стране банке у последњих шест месеци пре покретања поступка могу да се оспоре пред судом ако су неки повериоци таквим пословима доведени у повољнији положај. Ако су послови закључени са повезаним лицима, они се могу оспорити ако су закључени у последњих годину дана. Пребој дугова повериоца са дуговима банке према том лицу може се извршити пре доношења одлуке о главној деоби. У стечајном поступку, продаја дужника банке као правне целине није дозвољена.

АОД утврђује основаност потраживања поверилаца у року од шест месеци од истека рока за пријављивање потраживања. Након тога, у року од 60 дана, одржава се рочиште у суду на којем се саставља коначан списак потраживања.

Ликвидациони поступак је сличан стечајном поступку, осим што се не формира одбор поверилаца (јер банка која је у питању способна је за плаћање, па повериоци немају потребу за таквом врстом заштите). Органи поступка су суд и ликвидациони управник, односно АОД.

„Закон о стечају и ликвидацији банака и друштава за осигурање" има релативно мали број одредаба, упућујући уместо тога на правила редовног стечајног поступка за обична (нефинансијска) при-

${ }^{6}$ Агенција за осигурање депозита, http://www.aod.rs. 
вредна друштва за питања која нису посебно уређена овим законом (Васиљевић, Београд, 2012, стр. 455-460; Đurić, 2012, стр. 159-171).

Међутим, широк спектар мера које се могу предузети у периоду пре покретања стечаја или ликвидације регулисан је Законом о банкама („Закон о банкама”, Службени гласник Републике Србије, бр. 107/2005, 91/2010 и 14/2015. Детаљније на званичној страници Народне банке Србије: www.nbs.rs). Закон о банкама знатно је измењен 2015. године, између осталог под утицајем БРРД. Једна од најзначајнијих промена је увођење поступка реорганизације, који је уређен у неким детаљима. Надлежни национални орган за реструктурирање банака је Народна банка Србије - централна банка. Све у свему, са изменама и допунама Закона о банкама, НБС добила је много активнију улогу у праћењу дневног пословања банака како би била у стању да интервенише на време и на одговарајући начин, са што могуће мање штете по укупну финансијску стабилност и друге учеснике на тржишту. Ова врста законодавне промене је у потпуности у складу са променама у прописима ЕУ које су последица финансијске кризе (Đurić, 2013, стр. 59-67).

На пример, банке су обавезне да припреме план за опоравак, који ће се примењивати у случају значајног погоршања њиховог финансијског стања. Ти планови опоравка достављају се на годишњем нивоу НБС, или чешће, ако је потребно (на захтев НБС). Стога, одредбе о плановима опоравка су у складу са одредбама БРРД. Одредбе о надзорној улози НБС у анализи извештаја ревизије банака такође су строже постављене. Као што смо већ истакли, НБС има много већу улогу и надлежности у праћењу пословања банака, укључујући и неке мере које су постојале у законима Србије до ових најновијих измена и допуна Закона о банкама. Исто тако, строжи систем одговорности успостављен је за примену и унутар самих банака.

Реструктурирање банака успостављено је као посебан поступак који се примењује када постоји потреба да се осигура одржавање критичних функција банака, заштити стабилност финансијског система у целини, заштите државни фондови, депоненти, инвеститори и клијенти банке и њихове имовине. Главни принципи у поступку реструктурирања су: први који ће носити губитке су акционари банке (јасна одредба да јавни фондови треба да буду поштеђени и да се не могу користити за покривање губитака у приватном финансијском сектору); следећи који треба сносе губитке су повериоци банке, али у истом редоследу као да је отворен поступак стечаја или ликвидације; депозити осигурани по закону биће исплаћени у целости; чланови управе банке биће смењени, али ће бити у обавези да помогну у процесу реструктурирања и биће законски одговорни за штету коју су евентуално својим поступањем проузроковали банци и њеним повериоцима. 
Мере попут оних које су донете новим законима одражавају не само потребу да се предметно српско законодавство прилагоди прописима ЕУ у овој области него и чињеницу да је Србија имала неколико случајева пропалих банака у последњих неколико година, са једном посебношћу: те банке су већ биле (у тренутку када је стечај постао јасан и непосредан) скоро у потпуности у власништву државе. Због тога, српски порески обвезници су већ упознати са ситуацијом када губици финансијских установа падају на крају и непосредно на терет државног буџета. То је управо ситуација са прописима ЕУ, као и са српским прописима, са циљем да се такве ситуације избегну у будућности.

\section{3. ПРОПИСИ У ЦРНОЈ ГОРИ}

Поступак стечаја и ликвидације банака у Црној Гори уређен је у Закону о стечају и ликвидацији банака (,Закон о стечају и ликвидацији банака", Служббени лист Републике Црне Горе, бр. 47/2001, 62/2008 и 44/2010. Детаљније на званичној страници Централне банке Црне Горе: www.cbmn.org). Основна карактеристика оба поступка је да их спроводи искључиво Централна банка Црне Горе (у даљем тексту: ЦБЦГ). ЦБЦГ покреће поступак, именује стечајног или ликвидационог управника и чланове стечајног одбора и одлучује о закључењу стечаја или ликвидације. Стечајни или ликвидациони управник је физичко лице које испуњава критеријуме утврђене законом. Закон садржи детаљне одредбе о поступку, у којем стечајни (или ликвидациони) управник има главну улогу, али је за свој рад одговоран стечајном одбору и ЦБЦГ. За разлику од стечаја обичних компанија у Црној Гори, судови не учествује у стечајном поступку над банкама, осим у случају тужби против управних аката ЦБЦГ у стечајном поступку (Vučinić, 2015, p. 63-93).

Закон о банкама (,Закон о банкама”, Службени лист Републике Црне Горе, бр. 17/2008, 44/2010 и 40/2011, www.cbmn.org) прописује неколико мера које се могу предузети од стране ЦБЦГ у случају да се у надзору утврди да је банка пословала незаконито или на неисправан начин, посебно у вези са управљањем ризицима. Те мере укључују различите налоге и забране (који ефективно значе мешање у дневно пословање банке), налог банци да припреми план опоравка банке, увођење привремене управе у банку или чак одузимање дозволе за рад банци (Žugić, 2013, p. 5-19). У случају увођења привремене управе, ЦБЦГ именује привременог управника, који преузима управљање банком и одговоран је за рад ЦБЦГ. Привремени управник може наредити емисију нових акција банке (емисија само постојећим акционарима, што је примарни начин, осим у случају већ пропале докапитализације), или продају акција постојећим акционарима ради подизања новог капитала, или чак пренос у средства и/или обавеза банке на другу банку, без сагласности акционара, поверилаца или 
дужника. Ове мере могу се упоредити са онима које је увео БРРД, иако дефинитивно нису последица доношења БРРД, пошто су последње измене и допуне Закона о банкама усвојене 2011. године (Report on analytical survey of harmonisation of legislation of the Republic of Montenegro, Chapter 9 - Financial services, Ministry of foreign affairs and European integrations of Montenegro, official website, www.mvpei.gov.me, 14. 9. 2015).

\section{4. ПРОПИСИ У БИВШОЈ ЈУГОСЛОВЕНСКОЈ РЕПУБЛИЦИ МАКЕДОНИЈИ}

Закон о банкама Македоније („Закон за банките”, Службен весник на РМ, бр. 67/2007, 90/2009, 67/2010, 26/2013 и 15/2015. Детаљније на званичној страници Народне банке Македоније: http://www.nbrm.mk) садржи одредбе којима се уређују поступак стечаја и ликвидације за банке, као и широк спектар мера које се могу предузети пре покретања таквог поступка (Petrovska, Mucheva Mihajlovska, 2013, p. 85-110), када банке наилазе на потешкоће приликом пословања. Док стечајни поступак може покренути гувернер Народне банке Републике Македоније, ликвидациони поступак може покренути или сама банка или гувернер Народне банке. Када стечајни поступак покреће гувернер Народне банке, он након доношења одлуке да су испуњени услови за покретање стечајног поступка подноси предлог за отварање поступка суду. Стечајни поступак спроводи суд, који именује стечајног управника, након добијања мишљења гувернера Народне банке за његово именовање. Стечајни управник мора бити (физичко) лице које испуњава законске услове за члана управе банке. Суд такође именује одбор поверилаца. Народна банка је такође укључена у поступак, пошто стечајни управник саставља извештај о свим потраживањима и обавезама банке и шаље извештај Народној банци, која га шаље стечајном суду после увида у примљена документа. Све одредбе о стечајном поступку нису садржане у $3 a$ кону о банкама, јер овај закон често упућује на одредбе Закона о стечају („Закон за стечај”, Службен весник на РМ, бр. 34/2006, 126/2006, 84/2007, 47/11, 79/13 и 29/14, Министерство за економија на PM, www.archive.economy.gov.mk/stecaj, 14. 9. 2015), којим је уређен стечајни поступак за обичне компаније.

Македонски Закон о банкама садржи цело поглавље посвећено филијалама банака из земаља чланица ЕУ, што значи да македонски закон даје банкама које долазе из ЕУ посебан статус (Boshkoska, 2013, p. 143-151), поједностављен приступ македонском банкарском тржишту кроз филијале (Malović, Paunović, 2012, стр. 564-588). Наиме, македонски Закон о банкама садржи другачији скуп правила за стране банке које нису из земаља чланица ЕУ. Закон о банкама, такође, прописује да је једини надлежни орган за одлучивање о отва- 
рању поступака стечаја или ликвидације над банкама, укључујући њене филијале у Македонији, орган матичне земље (Fotov, Fotova Cikovikj, 2015, p. 262-277). Ова, као и остале одредбе Закона о банкама, усклађена је са одредбама Директиве 2001/24/ЕС о реорганизацији и ликвидацији кредитних установа.

Закон о банкама такође поверава гувернеру Народне банке, као надлежном органу, широки обим мера које би могле бити предузете у случају уочене неправилности у пословању банке, укључујући и увођење управе или именовање нових чланова од управе банке која се суочава са тешкоћама.

\section{ЗАКЉУЧАК}

Анализа стања законодавства у одабраним земљама кандидатима за ЕУ показује општи тренд прилагођавања посткризним условима на тржишту банака, који је донекле под утицајем промена у прописима ЕУ у овој области. Иако се може рећи да је Србија на најдиректнији начин одговорила на доношење нових прописа ЕУ, као што је БРРД, јасно је да друге земље припремају своја тржишта за изазове преговора о приступању ЕУ. На пример, Македонија је у своје законодавство већ увела посебан третман за банке које потичу из земаља ЕУ, што олакшава њихов приступ македонском тржишту. Међутим, будућност банкарских прописа земаља кандидата је и даље неизвесна, а мора се рећи да исход у потпуности не зависи од квалитета националних закона и њихове примене. Политичке и економске околности су у последње време ставиле друге теме на дневни ред (имиграциона криза, кризе у Грчкој, криза у Украјини, спор економски раст у многим земљама чланицама ЕУ), што значи да проширење ЕУ тренутно није у озбиљном разматрању. Такође, и даље треба да се утврди какав би ефекат у случају нове финансијске кризе имали сами прописи ЕУ, који треба да се користе као модел за земље кандидате. Процес примене и оцене законодавства земаља кандидата је процес који ће сигурно трајати годинама.

\section{ЛИТЕРАТУРА}

Анић А., Маловић М., Мисић В. (2015). Макроекономско окружење и проблематични кредити - пример Србије и Републике Чешке [Macroeconomic environment and NPLS: evidence from Serbia and the Czech Republic]. y: М. Секуловић (ур.), Теме: часопис за друитвену теорију и праксу, 1/2015, Ниш, стр. 175-190.

Boshkoska M. (2013). The Profitability of Banking Sector in Republic of Macedonia, y: Olajide S. Oladipo (Ed.), International Journal of Economics and Finance, Toronto 2013, Vol. 5, No. 3, p. 143-151. 
Burkert M. (2015 September). Legal analysis of Valuation and Bail-In - The Core Elements of Future Banking Resolution. Paper presented at the INSOL Europe Conference Banking and Financial Insolvencies, Berlin 2012.

Đurić Đ. (2013). The bankruptcy law of the Republic of Serbia in times of crisis, y: Economic science on the crossroad, Institut ekonomskih nauka Beograd, стр. $59-67$.

Đurić Đ. (2012). Serbian Insolvency Law and its relation to EU Insolvency Standardization and the US Bankruptcy Code, in: Rebecca Parry (Ed.), Substantive Harmonisation and Convergence of Laws in Europe, INSOL Europe, Nottingham-Paris, стр. 159-171.

Fotov R., Fotova Cikovikj K. (2015). Consolidation of the banking sector in Macedonia: Effects and Benefits, y: Vladimir Filipovski (Ed.) Economic recovery in the postcrisis period, Faculty of Economics Skopje, 1 (1). p. 262-277.

Ivanović P., Balaban M. (2009). The impact of global financial crisis on Serbian banking sector - the NBS response, y: Claude Berthomieu etc. (Ed.), Financial systems integration of Balkan countries in the European Financial system: Impact of global financial crisis, University of Nice - Sophia Antipolis, Institute of Economic Sciences Belgrade, p.43-52.

Јовановић Н. (2011). Нови законодавни „мућак” Србије у МиФИД окружењу [New legislative "rotten egg" of Serbia in MIFID environment]. у: Усклађивање пословног права Србије са правом Европске уније, Правни факултет Универзитета у Београду, Београд, стр. 228-304.

Malović M., Paunović S. (2012). Flow of Funds in Balkan Banks: Narrow Banking or Narrow Escape?, y: Teixeira P. et alia (eds.). European Integration Process in Western Balkan Countries, University of Coimbra Press, Coimbra, стр. 564-588.

Миљковић Божић И. (2012). Економска модернизација Србије и међународни економски токови [Comparative analysis of the causes and consequences of representative banking crises]. у: М. Секуловић (ур.), Теме: часопис за друштвену теорију и праксу, 4/2012, Ниш, стр. 1739-1761.

Petrovska M., Mucheva Mihajlovska E. (2013). Measures of Financial Stability in Macedonia, y: Nikola Fabris (Ed.) Journal of Central Banking Theory and Practice, Central Bank of Montenegro, Podgorica 2013, N³, p. 85-110.

Раденковић Јоцић Д., Станковић Ј., Анђелковић Пешић М. (2012). Хармонизација регулативе о управљању ризиком у банкарском сектору Србије [Harmonization of risk management regulations in the banking sector in Serbia]. у: М. Секуловић (ур.), Теме: часопис за друитвену теорију и праксу, 3/2012, Ниш, стр. 1193-1214.

Report on analytical survey of harmonisation of legislation of the Republic of Montenegro, Chapter 9 - Financial services, Ministry of foreign affairs and European integrations of Montenegro, official website, www.mvpei.gov.me, 14. 9. 2015.

Тодоровић В., Вуксановић Е., Јакшић М. (2015). Компаративна анализа узрока и последица репрезентативних банкарских криза [Comparative analysis of the causes and consequences of representative banking crises]. y: М. Секуловић (ур.), Теме: часопис за друитвену теорију и праксу, 1/2015, Ниш, стр. $159-174$.

Васиљевић М. (2012). Компанијско право [Company Law]. „Службени гласник РС”, Београд.

Вуњак Н., Давидовић М., Стефановић М. (2012). Утицај глобалне финансијске кризе на перформансе банкарског сектора Србије [The impact of the global financial crisis on the performances of the Serbian banking sector]. y: М. Секуловић (ур.), Теме: часопис за друштвену теорију и праксу, 3/2012, Ниш, стр. 1279-1298. 
Vučinić M. (2015). Financial Stability - Comparative Analysis: Montenegro, Serbia and the Netherlands, y: Nikola Fabris (Ed.) Journal of Central Banking Theory and Practice, Central Bank of Montenegro, Podgorica 2015, N 1, p. 63-93.

Žugić R. (2013). Crisis management and the banking system in Montenegro, y: Nikola Fabris (Ed.) Journal of Central Banking Theory and Practice, Central Bank of Montenegro, Podgorica 2013, Nº1, p. 5-19.

Директива 2001/24/ЕС од 4. априла 2001. о реорганизацији и ликвидацији кредитних установа [Directive 2001/24/EC from April 4th 2001 on the reorganisation and winding up of credit institutions]. OJ L 125, 5. 5. 2001, стр. 15-23.

Директива 2014/59/EU 15. маја 2014. о успостављању оквира за санацију и опоравак кредитних установа и инвестиционих друштава [Directive 2014/59/EU from May $15^{\text {th }} 2014$ establishing a framework for the recovery and resolution of credit institutions and investment firms]. OJ L 173, 12. 6. 2014, стр. 190-348.

Закон о банкама [Law on Banks], Службени гласник Републике Cрбије [Official Gazette of the Republic of Serbia]. бр. 107/2005, 91/2010 и 14/2015.

Закон о банкама [Law on Banks], Службени лист Републике Црне Горе [Official Gazette of the Republic of Montenegro]. бр. 17/2008, 44/2010 и 40/2011.

Закон за банките [Law on Banks], Службен весник на PM [Official Gazette of the Republic of Macedonia]. бp. 67/2007, 90/2009, 67/2010, 26/2013 и 15/2015.

Закон за стечај [Bankruptcy Law], Службен весник на PM [Official Gazette of the Republic of Macedonia]. бр. 34/2006, 126/2006, 84/2007, 47/11, 79/13 и 29/14.

Закон о стечају и ликвидацији банака и друштава за осигурање [Law on Bankruptcy and Liquidation of the banks and insurance companies], Службени гласник Републике Србије [Official Gazette of the Republic of Serbia]. бp. 14/2015.

Закон о стечају и ликвидацији банака [Law on Bankruptcy and Liquidation of the banks and insurance companies], Службени лист Републике Црне Горе [Official Gazette of the Republic of Montenegro]. бp. 47/2001, 62/2008 и 44/2010.

\title{
INSOLVENCY OF BANKS AND FINANCIAL INSTITUTIONS THE EU CANDIDATE COUNTRIES IN WESTERN BALKANS
}

\author{
Đuro M. Đurić ${ }^{1}$, Vladimir M. Jovanović ${ }^{2}$, Mirjana M. Misailović ${ }^{3}$ \\ ${ }^{1}$ Chamber of Enforcement Agents, Belgrade, Serbia \\ ${ }^{2}$ Faculty for Economy and Engeneering Management in Novi Sad, Serbia \\ ${ }^{3}$ Institute for Textbooks and Teaching Aids, Belgrade, Serbia
}

\section{Summary}

The analysis of the state of legislation in the selected EU candidate countries shows a general trend of adapting to the post-crisis conditions of the banking markets, which is also somewhat influenced by the changes in the EU regulations in this field. While it can be said that Serbia has responded in the most direct manner to the new EU regulations, such as BRRD, it is clear that other countries are also preparing their respective markets for the challenges of the EU accession negotiations. For example, FYR Macedonia has already introduced a special treatment for banks that originate from the EU states into legislation, which facilitates their access to Macedonian market. However, the future of banking regulations of candidate countries is still uncertain, and it must be said that the outcome is not entirely dependent on the quality of their laws and their implementation. 
Political and economic circumstances have put other topics on the agenda lately (immigration crisis, Greek crisis, Ukrainian crisis, slow economic growth in many EU member states), which means that the EU enlargement is currently not under serious consideration. Also, it is still to be determined how the EU regulations themselves, which are to be used as a model for the candidate countries, would perform in case of a new financial crisis. The process of testing and evaluation of legislation of candidate countries is a process that will certainly take years. 